\title{
EKSPLORASI KANDUNGAN KIMIA DARI SISIK IKAN AIR PAYAU UNTUK PENGEMBANGAN BIOMATERIAL FUNGSIONAL DI INDUSTRI FARMASETIKA
}

\section{EXPLORATION OF CHEMICAL CONTENTS OF BRACKISH FISH SCALES FOR THE DEVELOPMENT OF FUNCTIONAL BIOMATERIALS IN THE PHARMACEUTICAL INDUSTRY}

\author{
Stephanie Bija ${ }^{1 *}$, Aldian ${ }^{1}$, Anhar Rozi ${ }^{2}$ \\ ${ }^{1}$ Program Studi Teknologi Hasil Perikanan, Fakultas Perikanan dan Ilmu Kelautan, \\ Universitas Borneo Tarakan, Amal Lama 77115 Kalimantan Utara \\ ${ }^{2}$ Program Studi Teknologi Hasil Perikanan, Fakultas Perikanan dan Ilmu Kelautan, \\ Universitas Teuku Umar Meulaboh, Meulaboh 23615 Aceh Barat \\ *email : bijastephanie92@gmail.com
}

\begin{abstract}
ABSTRAK
Kekayaan alam Indonesia tersedia dalam jumlah yang melimpah, salah satunya Perairan payau dan berpotensi untuk dikembangkan menjadi bahan baku pembuatan obat. Eksplorasi terhadap kandungan kimia sisik ikan payau yang ada di Perairan sekitar Kota Tarakan diharapkan dapat menjadi solusi untuk mengatasi permasalahan sediaan bahan baku farmasetika di Indonesia. Tujuan penelitian ini adalah mengetahui kandungan kimia yang terdapat pada sisik ikan payau, sebagai bahan dasar dalam upaya pengembangan dan pemanfaatannya di bidang farmasetika. Metode penelitian terdiri dari dua tahap, yaitu penanganan sampel sisik ikan payau dan eksplorasi kandungan kimianya. Analisis terhadap komponen-komponen kimia dilakukan melalui pengujian proksimat (kadar air, kadar abu, kadar lemak, kadar protein, dan kadar karbohidrat. Hasil penelitian menunjukkan bahwa kandungan protein ikan bandeng (Chanos chanos), ikan belanak (Mugil cephalus), dan ikan bulan-bulan (Megalops cyprinoides) secara berturut-turut, yaitu 54,5\%; 57,6\%; dan 55\%. Kandungan lemak ikan bandeng (2,46\%), ikan belanak (2,25\%), ikan bulan-bulan $(2,03 \%)$. Kandungan karbohidrat ikan bandeng $(2,15 \%)$, ikan belanak $(2,42 \%)$, ikan bulan-bulan $(1,98 \%)$. Kadar air pada ikan bandeng 11,9\%; ikan belanak 6,73\%; dan ikan bulan-bulan $(8,0 \%)$, sedangkan kadar abu pada ketiga ikan secara berturut-turut, yaitu $29 \%, 31 \%$, dan $33 \%$. Kandungan tertinggi pada analisis proksimat adalah protein.
\end{abstract}

Kata kunci: biomaterial, farmasetika, proksimat, obat.

\begin{abstract}
Indonesia has abundant natural resources, such as brackish waters and it is potential to be developed into raw materials for medicine. Exploration to the chemical content of brackish fish scales in the waters around Tarakan city is expected to solve the problem of pharmaceutical raw material supplies in Indonesia. The purpose of this study was to determine the chemical content of brackish fish scales, as a basic ingredient in efforts to develop and utilize it in pharmaceuticals field. The research method consisted of two stages, they are handling and exploring chemical content of brackish fish scales. The analysis was carried out through proximate test (water, ash, fat, protein, and carbohydrate content). The results showed that the protein of milkfish (Chanos chanos), belanak fish (Mugil cephalus), and bulan-bulan fish (Megalops cyprinoides) were 54.5\%; 57.6\%; and 55\%. Fat content of
\end{abstract}


milkfish $(2.46 \%)$, belanak fish $(2.25 \%)$, bulan-bulan fish $(2.03 \%)$. The carbohydrate content of milkfish $(2.15 \%)$, belanak fish $(2.42 \%)$, bulan-bulan fish $(1.98 \%)$. Water content of milkfish $11.9 \%$; belanak fish $6.73 \%$; and bulan-bulan fish $(8.0 \%)$, while the ash content were $29 \%, 31 \%$, and $33 \%$, respectively. The highest content in proximate analysis was protein.

Keywords: biomaterial, medicine, pharmaceuticals, proximate

\section{PENDAHULUAN}

Farmasetika adalah salah satu bidang ilmu yang fokus dalam perkembangan ilmu dan teknologi pembuatan obat serta menyediakan obat menjadi bentuk tertentu sehingga siap untuk dipakai. Ketersediaan obat saat ini masih merupakan suatu masalah dalam bidang kesehatan, salah satunya adalah tingginya permintaan obat generik tetapi stok tidak ada (Satibi et al. 2019). Salah satu permasalahannya adalah bahan baku farmasi, baik untuk pembuatan obat, suplemen, maupun kosmetik saat ini masih importir dari negara luar, bahkan bahan baku sediaan obat sekitar 90\% berasal dari luar negeri (Angga 2018). Hal ini tentu saja berdampak pada lambatnya proses pengiriman sehingga membutuhkan waktu tunggu yang lama. Indonesia perlu mengembangkan industri farmasi terutama industri bahan baku obat untuk memenuhi kebutuhan masyarakat.

Pembuatan bahan baku obat membutuhkan bahan-bahan dasar dalam jumlah besar dan tersedia dalam jumlah yang cukup selama proses produksi. Kekayaan alam Indonesia tersedia dalam jumlah yang melimpah dan berpotensi untuk dikembangkan menjadi obat. Penelitian yang dilakukan oleh Kim dan Venkatesan (2013) menyatakan bahwa sumber daya laut mempunyai potensi biomaterial untuk dikembangkan sebagai bahan baku farmasetika. Hal ini tidak menutup kemungkinan bahwa organisme di Perairan darat, salah satunya air payau juga dapat dieksplorasi. Kota Tarakan mempunyai potensi sumberdaya perikanan yang cukup tinggi, khususnya organisme air payau. Beberapa jenis ikan air payau yang banyak ditemukan di Perairan sekitar Kota
Tarakan, diantaranya adalah jenis ikan bandeng, ikan bulan-bulan, dan ikan belanak.

Jenis ikan air payau ini banyak dimanfaatkan oleh masyarakat menjadi produk olahan ikan. Ikan bandeng diolah menjadi Bandeng tanpa duri (Baduri), ikan bulan-bulan diolah menjadi nuget dan bakso ikan sedangkan ikan belanak biasanya digoreng. Pengolahan yang dilakukan terhadap ketiga ikan ini ternyata menyisakan limbah hasil samping berupa sisik ikan. Sisik ikan masih sangat jarang dimanfaatkan dan penelitian terhadap sisik ikan air payau masih sangat terbatas. Penelitian yang sudah banyak dilakukan yaitu mengenai diversifikasi olahan pada ikan bulan-bulan (Mufarihat et al. 2019) dan ikan bandeng (Sugito et al. 2019), penelitian terhadap ikan belanak masih sebatas pada pertumbuhan dan studi hispatologi hati ikan belanak (Sari dan Perwira 2019), sedangkan penelitian terhadap kandungan kimia, khususnya pada sisik ketiga ikan ini masih sangat jarang dilakukan. Eksplorasi terhadap kandungan kimia pada sisik ikan air payau dapat dilakukan melalui analisis proksimat untuk mengetahui kadar air, kadar abu, kadar lemak, kadar protein, dan kadar karbohidrat. Suatu bahan dapat diproses menjadi suatu produk senyawa yang berguna bagi kehidupan manusia jika diketahui kadar dari komponen kimia di dalamnya (Talumepa et al. 2016).

Di Tarakan, belum ada dilaporkan pemanfaatan sisik ikan sebagai bahan baku pengembangan biomaterial fungsional, khususnya di bidang farmasetika. Oleh karena itu, penelitian ini dapat menjadi langkah awal sebagai penyedia material khusus dalam bidang farmasetika di masa 
akan datang. Tujuan penelitian ini adalah menganalisis kandungan kimia, yang terdapat pada sisik ikan payau sebagai bahan dasar dalam upaya pengembangan dan pemanfaatannya di bidang farmasetika.

\section{METODOLOGI}

\section{Waktu dan tempat}

Penelitian ini dilaksanakan pada bulan Agustus 2020 - Oktober 2020 di Laboratorium Nutrisi dan Pakan, Fakultas Perikanan dan Ilmu kelautan Universitas Borneo Tarakan.

\section{Alat dan Bahan}

Peralatan yang digunakan selama penelitian adalah makro kjedahl, soklet, oven, tanur, dan peralatan gelas lainnya. Bahan utama adalah limbah sisik ikan bandeng, ikan belanak, dan ikan bulanbulan yang diperoleh dari beberapa pasar di Kota Tarakan. Bahan-bahan penunjang yaitu aquades, natrium tiosulfat $\left(\mathrm{Na}_{2} \mathrm{SO}_{4}\right)$, asam sulfat $\left(\mathrm{H}_{2} \mathrm{SO}_{4}\right) 0,1 \mathrm{~N}$, asam borat $\left(\mathrm{H}_{3} \mathrm{BO}_{3}\right) 4 \%$, dan natrium hidroksida $(\mathrm{NaOH}) 40 \%$.

\section{Metode Pengambilan Sampel}

Sisik ikan payau yang telah kering dianalisis kandungan kimianya, meliputi perhitungan kadar air, kadar abu, kadar lemak, kadar protein, dan kadar karbohidrat.

\section{Kadar air (AOAC 1995)}

Cawan porselin kosong dikeringkan pada suhu $105^{\circ} \mathrm{C}$ selama 1 jam, kemudian cawan tersebut didinginkan dalam desikator dan ditimbang beratnya (A gram). Cawan yang telah ditimbang tersebut diisi dengan sampel sebanyak 5 gram dan ditimbang beratnya (B gram). Cawan yang sudah berisi sampel tersebut dimasukkan ke dalam oven bersuhu $105{ }^{\circ} \mathrm{C}$ sampai beratnya konstan. Kadar air dihitung berdasarkan persamaan:

$$
\begin{aligned}
& \text { Kadar air }(\%)=\frac{(\mathrm{B}-\mathrm{A})}{\text { berat contoh }} \times 100 \% \\
& \text { Keterangan: } \\
& \mathrm{A}=\text { berat cawan }+ \text { contoh kering }(\mathrm{g})
\end{aligned}
$$

$$
\mathrm{B}=\text { berat cawan }+ \text { contoh basah }(\mathrm{g})
$$

\section{Kadar abu (AOAC 1995)}

Cawan dibersihkan dan dikeringkan dalam oven selama 30 menit pada suhu $105^{\circ} \mathrm{C}$, lalu didinginkan dalam desikator dan ditimbang. Sampel sebanyak $1 \mathrm{~g}$ ditimbang lalu dimasukkan ke dalam cawan, kemudian dibakar diatas kompor listrik sampai tidak berasap lagi dan selanjutnya dimasukkan dalam tanur pengabuan dengan suhu $650^{\circ} \mathrm{C}$ selama 5 jam. Cawan didinginkan dalam desikator dan kemudian ditimbang. Kadar abu ditentukan dengan rumus:

$$
\text { Kadar abu }(\%)=\frac{\text { berat abu }}{\text { berat sampel }} \times 100 \%
$$

\section{Kadar lemak (AOAC 1995)}

Labu lemak dikeringkan pada suhu $110^{\circ} \mathrm{C}$, lalu dimasukkan ke dalam desikator dan ditimbang. Sampel sebanyak 5 gram yang telah dibungkus dengan kertas saring dimasukkan ke dalam alat ekstraksi, lalu dilakukan proses reflux hingga larutan jernih dan pelarut yang ada di dalam labu lemak berwarna jernih. Labu lemak yang berisi lemak hasil ekstraksi selanjutnya dipanaskan pada suhu $105^{\circ} \mathrm{C}$ hingga beratnya konstan, lalu dimasukkan ke dalam desikator dan ditimbang.

$$
\text { Kadar lemak }(\%)=\frac{(B-A)}{\text { berat contoh }} \times 100 \%
$$

Keterangan :

$\mathrm{A}=$ berat labu lemak kosong (gram)

$\mathrm{B}=$ berat labu lemak dengan lemak (gram)

\section{Kadar protein (AOAC 1995)}

Sampel 0,5 gr dimasukkan ke dalam labu kjeldahl $50 \mathrm{~mL}$, lalu ditambahkan kjeltab dan 2,5 $\mathrm{mL} \mathrm{H}_{2} \mathrm{SO}_{4}$ pekat. Campuran tersebut dibiarkan sampai dingin, kemudian dipindahkan ke alat destilasi. Selanjutnya ditambahkan $10 \mathrm{~mL} \mathrm{NaOH}$ pekat sampai berwarna coklat kehitaman, lalu didestilasi. Hasil destilasi ditampung dalam erlenmeyer $125 \mathrm{~mL}$ yang berisi $5 \mathrm{~mL} \mathrm{H}_{3} \mathrm{BO}_{3}$ dan indikator metilen blue, lalu dititrasi dengan larutan $\mathrm{HCl} 0,02 \mathrm{~N}$ sampai berubah menjadi 
warna pink. Larutan blanko dianalisis seperti contoh. Kadar protein dihitung dengan persamaan di bawah ini:

Kadar Nitrogen $(\%)$ :

$=\frac{(\mathrm{Vs}-\mathrm{Vb}) \times \mathrm{N} \mathrm{HCl} \times 0,014 \times \mathrm{fk} \times \mathrm{fp}}{\mathrm{W}} \times 100 \%$

Keterangan :

$\mathrm{W}=$ berat sampel

$\mathrm{Vs}=$ Volume $\mathrm{HCl}$ yang digunakan pada titrasi sampel

$\mathrm{Vb}=$ Volume $\mathrm{HCl}$ yang digunakan pada titrasi larutan blanko

$\mathrm{fk}=$ protein dari makanan secara umum $(6,25)$

$\mathrm{fp}=$ faktor pengenceran

\section{Kadar karbohidrat}

Kadar karbohidrat $(\%)=$ $100 \%$ - [(\%kadar air +\%kadar abu + $\%$ kadar lemak + \%kadar protein)]

\section{Analisis Data}

Data yang diperoleh dianalisis secara deskriptif dan dinyatakan dalam bentuk persentase (\%). Data tersebut dibandingkan dengan referensi untuk menjelaskan karakteristik sampel dari hasil penelitian yang diperoleh.

\section{HASIL DAN PEMBAHASAN}

\section{Karakteristik Proksimat dari Sisik Ikan Air Payau}

Komposisi kimia setiap ikan berbedabeda tergantung pada jenis ikan, antar individu dalam spesies, dan antar bagian tubuh dari satu individu ikan. Perbedaan ini dapat disebabkan oleh beberapa faktor yaitu umur, laju metabolisme, pergerakan ikan, makanan, serta masa reproduksi. Selain itu perbedaan komposisi kimia daging juga tergantung dari umur, habitat dan kebiasaan makan. Komposisi kimia daging ikan umumnya terdiri dari kadar air 70-85\%; protein $15-25 \%$; lemak 1-10\%; karbohidrat 0,1-1\% dan mineral 1-1,5\% (Okada, 1990). Komposisi proksimat ikan berbeda pada habitat yang berbeda, hal ini dikemukakan oleh Aziz et al. (2013) bahwa komposisi proksimat ikan berbeda pada habitat air payau dan air tawar. Komposisi proksimat dari beberapa ikan air payau dapat dilihat pada Tabel 1.

Tabel 1. Hasil analisis proksimat sisik ikan air payau

\begin{tabular}{lccc}
\hline Komposisi proksimat & Ikan bandeng & Ikan belanak & Ikan bulan-bulan \\
\hline Karbohidrat (\%) & 2,15 & 2,42 & 1,98 \\
Protein (\%) & 54,5 & 57,6 & 55,0 \\
Lemak (\%) & 2,46 & 2,25 & 2,03 \\
Air (\%) & 11,9 & 6,73 & 8,0 \\
Kadar Abu (\%) & 29,0 & 31,0 & 33,0 \\
\hline
\end{tabular}




\section{Kadar Karbohidrat}

Karbohidrat merupakan sumber kalori yang murah. Karbohidrat memiliki peranan penting dalam menentukan karakteristik bahan makanan, misalnya rasa, warna, tekstur dan lain-lain (Winarno, 2004). Dalam bidang farmasi, karbohidrat banyak digunakan sebagai bahan pensuspensi, maupun bahan tambahan pada pembuatan tablet. Tablet merupakan salah satu jenis sediaan farmasi yang banyak dimanfaatkan karena mudah dalam penggunaan dan penyimpanan. Pada pembuatan tablet, sebagian besar bahan tambahan yang berasal dari karbohidrat adalah selulosa, gom, dekstrosa, dan laktosa. Bahan pengemulsi, pengencer, penghancur, penyalut, pelincir, adsorben, dan pembawa sebagian besar menggunakan karbohidrat sebagai bahan dasarnya (Ansel 2008). Jumlah karbohidrat dalam daging ikan sangat sedikit, yaitu berkisar 0,05-0,86\% (Gusrina, 2008). Berdasarkan Tabel 3 diperoleh bahwa kadar karbohidrat tertinggi yaitu pada ikan belanak sebesar 2,42\% . Menurut penelitian yang telah dilakukan oleh Heruwati (2002) menjelaskan tingginya kandungan karbohidrat pada seluruh spesies hanya mengindikasikan adanya perbedaan frekuensi nilai antara tiap-tiap kandungan gizi lainnya dari jumlah $100 \%$ total gizi.

\section{Kadar Protein}

Protein adalah molekul yang mempunyai fungsi vital dalam proses biokimia yang terjadi di dalam tubuh, seperti untuk reaksi katalisis (Deb et al. 2019), maupun sebagai transporter untuk proses keluar masuknya senyawa kimia pada sel (Sandag et al. 2019). Peran protein yang terlibat dalam aktivitas biologi tubuh membuat protein berpotensi dijadikan obat untuk terapi pengobatan suatu penyakit (Yuswadinata dan Wathoni, 2021). Hasil analisis nilai kadar protein pada sisik ikan payau menunjukkan bahwa uji kadar protein yang terbesar ada pada daging ikan belanak $57,6 \%$, pada ikan bandeng $54,5 \%$, dan ikan bulan-bulan 55,0\%. Perbedaan kandungan protein ini dapat disebabkan oleh banyak faktor, terutama perbedaan habitat, ukuran, jenis kelamin dan kondisi seksualitas dari ikan

\section{Kadar Lemak}

Lemak merupakan zat makanan yang penting untuk menjaga kesehatan tubuh manusia, selain itu minyak dan lemak merupakan sumber energi yang lebih efektif dibandingkan dengan karbohidrat dan protein (Winarno, 2004). Jenis lemak padat pada awalnya dipakai sebagai bahan baku pelet untuk memudahkan mobilitas obat (delivery drug), selanjutnya dikembangkan menjadi Solid lipid nanoparticle (SLN) (Rahmi 2010). Pada bidang farmasi, SLN dapat membantu membawa obat ke target pengobatan (Ernest et al. 2005). Lemak yang terkandung dalam ikan sangat mudah untuk dicerna langsung oleh tubuh dan sebagian besar terdiri dari asam lemak tak jenuh yang dibutuhkan untuk pertumbuhan dan dapat menurunkan kolesterol dalam darah (Hafiluddin et al, 2014). Hasil penelitian menunjukkan bahwa kadar lemak tertinggi pada ikan bandeng yaitu 2,46\% dibandingkan dengan ikan belanak $(2,25 \%)$ dan ikan bulan-bulan (2,03\%). Penelitian yang telah dilakukan oleh Patawi (1996) menyatakan bahwa faktor habitat tidak memberikan pengaruh nyata terhadap kadar lemak, sedangkan faktor wilayah berpengaruh nyata. Hal ini diduga karena kandungan protein pakan alami itu sendiri yang secara langsung tergantung pada lingkungannya.

\section{Kadar Air}

Air merupakan komponen kimiawi yang terbesar pada bahan pangan dan merupakan cairan yang esensial bagi hidup (Syah, 2012). Pada bidang farmasi, kandungan air yang berlebihan pada bahan atau sediaan obat tradisional akan mempercepat pertumbuhan mikroba dan mempermudah terjadinya hidrolisa terhadap kandungan kimianya sehingga dapat mengakibatkan penurunan mutu dari obat tradisional (Siswati 2020). Penghilangan 
kadar air hingga jumlah tertentu berguna untuk memperpanjang daya tahan bahan selama penyimpanan (Handayani 2017). Pada ketiga jenis ikan payau yang dianalisis, kadar air tertinggi yaitu ikan bandeng $(11,9 \%)$, ikan belanak $(6,73 \%)$, dan ikan bulan-bulan $(8,0 \%)$. Variasi kadar air selain dipengaruhi wilayah, juga dipengaruhi iklim tempat hidup ikan tersebut, kadar lemak total, umur ikan dan pertumbuhan ikan itu sendiri. Penelitian Sunarya et. al. (1995) menjelaskan bahwa kadar air pada ikan cenderung mempunyai pola perbandingan terbalik dengan kadar lemaknya, yaitu pada saat kadar air tinggi maka kadar lemak cenderung lebih rendah.

\section{Kadar Abu}

Kadar abu adalah zat anorganik sisa hasil pembakaran suatu bahan organik. Penentuan kadar abu berhubungan erat dengan kandungan mineral yang terdapat dalam suatu bahan, kemurnian serta kebersihan suatu bahan yang dihasilkan (Sudarmadji, 2003). Semakin tinggi kadar abu yang diperoleh, maka kandungan mineral dalam bahan juga semakin tinggi (Utami et al. 2020). Pada Tabel 3 terlihat bahwa kadar abu tertinggi yaitu ikan bulanbulan $(33,0 \%)$. Tinggi rendahnya kadar abu ini dipengaruhi oleh umur ikan yaitu semakin muda umur ikan maka kadar abunya semakin besar hal ini disebabkan karena pembentukan jaringan kerangka tubuh masih berlangsung sehingga mineralmineral atau zat anorganik yang dibutuhkan lebih banyak. Martinez et al. (1998) menjelaskan kandungan abu/mineral pada ikan juga tergantung pada faktor ekologis seperti musim, tempat pembesaran dan jumlah nutrisi yang tersedia. Mineral seperti kalsium, magnesium, dan fosfor sangat diperlukan oleh manusia untuk pertumbuhan tulang (Utami et al. 2020).

\section{KESIMPULAN DAN SARAN}

\section{Kesimpulan}

Kandungan kimia yang terdapat pada ketiga ikan payau berbeda-beda. Kadar karbohidrat pada ikan bandeng sebesar 2,15\%; ikan belanak 2,42\%; dan ikan bulan-bulan yaitu $1,98 \%$. Kadar protein ikan bandeng sebesar 54,5\%; ikan belanak 57,6\%; dan ikan bulan-bulan 55,0\%. Kadar lemak ikan bandeng sebesar 2,46\%; ikan belanak 2,25\%; dan ikan bulan-bulan $2,03 \%$. Kadar air ikan bandeng yaitu 11,9\%; ikan belanak $6,73 \%$; dan ikan bulan-bulan 8,0\%. Kadar abu pada ikan bandeng yaitu 29,0\%; ikan belanak $31,0 \%$; dan ikan bulan-bulan sebesar 33,0\% .

Hasil penelitian menunjukkan bahwa kadar tertinggi dari ketiga jenis sisik ikan air payau adalah kadar protein.

\section{Saran}

Perlu dilakukan penelitian lebih lanjut mengenai komposisi proksimat pada bagian organ tubuh yang lain sehingga semua bagian tubuh dapat dimanfaatkan secara optimal. Selain itu, perlu dilakukan penelitian mengenai metabolit sekunder pada ketiga jenis ikan payau untuk pengembangan dalam bidang farmasi.

\section{Ucapan Terima Kasih}

Ucapan terimakasih ditujukan kepada DIPA-UBT yang telah membiayai penelitian ini melalui hibah skema Penelitian Berbasis Visi Universitas Borneo Tarakan.

\section{DAFTAR PUSTAKA}

Angga D. 2018. Lebih 90\% Bahan obat diimpor. Kementrian Kesehatan Republik Indonesia. [Media Koran Sindo]. Hal.2.

Ansel HC. 2008. Pengantar bentuk sediaan farmasi. Jakarta:UI Press.

[AOAC] Association of Official Analytical Chemistry. 1995. Official methods of analysis. Marylandn (US): Association of Official Analytical Chemists Inc.

Aziz AF, Nematollahi A, Siavash, Saei DS. 2013. Proximate composition and fatty acid profile of edible tissues of 
Capoeta damascina (Valenciennes, 1842) reared in freshwater and brackish water. Journal of Food Composition and Analysis. 32:150154.

Deb, Pran Kishore. 2019. Protein/Peptide Drug Delivery Systems: Practical Consideration in Pharmaceutical Product Development. Basic Fundamental of Drug Delivery. Elsevier. 651-684.

Ernest SK. 2005. Nanotechnology, nanomedicine, and the development of new, effective therapies for cancer. Nanomedicine: Nanotechnology, Biology and Medicine. 1(2): 101-109.

Gusrina. 2008. Budidaya ikan jilid 2. Departemen pendidikan nasional. Jakarta.

Hafiluddin, Perwitasari Y, Budiarto S. 2014. Analisis kandungan gizi dan bau lumpur ikan bandeng (Chanos chanos) dari dua lokasi yang berbeda. Jurnal Kelautan. 7(1):33-44.

Handayani S. 2017. Penapisan fitokimia dan karakterisasi simplisia daun jambu mawar (Syzygium jambos Alston). Jf Fik Uinam. 5(3):179-180.

Heruwati ES. 2002. Pengolahan ikan secara tradisional: prospek peluang dan pengembangan. Jurnal Litbang Pertanian. 21:92-99.

Kim SK, Venkatesan J. 2013. Marine Biomaterials: Characterization, Isolation, and Applications. Boca Raton (US): CR Cpress

Martinez I, Santaella MRS, Periago MJ. 1998. Content and in vitro availability of Fe, $\mathrm{Zn}, \mathrm{Mg}$, and P. in homogenized fish-base weaning foods after bone addition. Food Chemistry. 63:299305.

Mufarihat IK, Haryati S, Munandar A. 2019. Karakteristik bontot dengan kombinasi daging ikan payus (Elops hawaiiensis) dan ikan bulan bulan (Megalops

cyprinoides).
JurnalPengolahan Hasil Perikanan Indonesia. 22(3):476-482.

Patawi A. 1996. Pengaruh habitat terhadap kandungan asam lemak omega-3 dan kolesterol pada udang windu (Panaeus monodon). [Skripsi]. Institut Pertanian Bogor:Bogor.

Rahmi D. 2010. Lemak padat nanopartikel; sintesis dan aplikasi. Jurnal Kimia dan Kemasan. 32 (1): 27-33.

Sandag, Green Arther, and Kaunang, Fergie. 2019. Klasifikasi Fungsi Family Protein Transport Menggunakan Radial Basis Neural Network. Cogito Smart Journal. 5:203-214.

Sari AHW, Perwira IY. 2019. Biomarker histopatologi hati ikan belanak (Mugil cephalus) sebagai peringatan dini toksisitas kromium (Cr) di Muara Tukad Badung, Bali. Journal of Marine and Aquatic Sciences. 5(2):229-233.

Satibi, Fudholi A, Tuko EC, Swastiandari GL. 2019. Pengendalian persediaan, fasilitas penyimpanan dan distribusi pada industri farmasi dalam mendukung ketersediaan obat era JKN. Jurnal Manajemen dan Pelayanan Farmasi. 9(1):27-37.

Siswati. 2020. Analisa kadar air dan kadar abu pada simplisia temu giring (Curcumae heyneana) dan simplisia kunyit (Curcumae domestica) di Balai riset dan standarisasi industri medan. [Skripsi]. Universitas Sumatera Utara. Sudarmadji S. 2003. Analisa bahan makanan dan pertanian. Liberty:Yogyakarta.

Sugito, Prahutama A, Tarno, Hoyyi A. 2019. Diversifikasi olahan ikan bandeng oleh UKM Primadona dalam program pengabdian IbPE 2016-2018. Jurnal Pengabdian kepada Masyarakat. 10(1):100-104.

Sunarya M, Fitriati, Mulyani H. 1995. The effect of season on fat content and fatty acid profile especially $n-3$ of yellowfin tuna. Suplement FAO Fisheries report no.154. Food and 
Agriculture Organization of The United Nation. Rome P. 205-209.

Syah, Dahrul. 2012. Pengantar Teknologi Pangan. IPB Press:Bogor.

Talumepa ACN, Suptijah P, Wullur S, Rumengan IFM. 2016. Kandungan kimia dari sisik beberapa jenis ikan laut. Jurnal LPPM Bidang Sains dan Teknologi. 3(1):27-33.

Utami YP, Sisang S, Burhan A. 2020. Pengukuran parameter simplisia dan ekstrak etanol daun patikala (Etlingera elatior (Jack) R.M. Sm) asal kabupaten Enrekang Sulawesi Selatan. Majalah Farmasi dan Farmakologi. 24(1):5-10.

Yuswadinata NS dan Wathoni N. 2021. Tinjauan bentuk sediaan farmasi mengandung peptida. Majalah Farmasetika. 6(1):121-128. 